\title{
Value Addition Policy in Nigeria's Export Processing Zones: Lessons from the Asian Economies
}

\author{
Deinibiteim Monimah Harry, Ph.D.
}

\author{
Department of Public Administration \\ Port Harcourt Polytechnic, \\ Rumuola, Port Harcourt, Nigeria
}

Doi: 10.2478/mjss-2018-0058

\begin{abstract}
The study examined the value addition in the Nigeria's export processing zones, comparing it with the experiences from Asian economies. Upon the recommendation of the United Nations Industrial Development Organization (UNIDO), Nigeria adopted the EPZ scheme via Decree No 63 of 1992 to accelerate industrialization through increasing manufacturing for exports, among others. The Calabar Free Trade Zone was established as the pioneer zone in the country. The objective of this research work is to determine the extent of Value Addition at the zones in Nigeria. As at 2008, 25 zones have registered with NEPZA, the regulatory authority in the country. Out of the 25 registered zones, 11are operational, 9 under construction and 5 merely declared. Four (4) zones, namely, Calabar, Oil and Gas and Snake Island Integrated Free Trade Zones and Alscon Export Processing zone, were systematically selected from the 11 operational zones for the study. Two hundred and ninety copies of questionnaire were administered on 290 respondents drawn from 54 firms and 4 zonal management boards. Out of the 290 copies of questionnaire 242 copies were properly filled and returned. The 242 copies of questionnaire returned served as the primary source of data, while textbooks, journals, fasimiles, etc served as the secondary sources of data. The paper argued that for EPZs to help in the industrialization of a nation value addition and production segmentation must be made central to the manufacturing/ production processes; because the higher the level of value addition the greater the impact/contribution of EPZs to socio-economic development. The study revealed that the level of value addition in the Nigerian zones is very low, only labour element of value addition is visible, technology and material elements were absent. Hence, the paper recommends that value addition should be made compulsory in the production processes at the zones and emphasis should be on the technology and material elements. This, it is believed would enhance backward linkages with the domestic economy.
\end{abstract}

Keywords: Backward linkages, Value Addition, Policy, Multiplier Effects, Foreign domination, and Production segmentation

\section{Introduction}

The initial success of the EPZ strategy in Ireland in 1958 encouraged the United Nations Industrial Development Organization (UNIDO) to recommend its adoption in the third world countries grappling with socio-economic development challenges in their states (Stein, 2008). This necessitated a proliferation of EPZs across the world, especially in Asia, Latin America and Africa. By 2006, there were 3,500 EPZs in 130 countries, employing 66 million people world-wide (Singa, 2007). However, scholars have argued that for EPZs to make significant impact on the socioeconomic development drive of a nation, they must greatly involve in manufacturing for exports and such manufactured exports must enjoy high level of value addition. Manufacturing refers to the physical and chemical transformation of materials into new products, regardless of the process (by 
machine or hand) and location (factory or home). On the other hand, value addition means enhancement made on a finished product/service before it is presented to the consumer. In the context of EPZs, therefore, value addition is the totality of inputs made to a finished product from the domestic or host economy.

Nigeria adopted the EPZ strategy via Decree No 63 of 1992, to among other things encourage the exports of manufactured goods and accelerate industrialization (NEPZA, 2008). The Calabar Free Trade Zone (CFTZ) was established in 1992 as a pioneer zone in the country, however, it was fully completed in 1999 and was formally commissioned for operations in 2001 (Harry, 2016). As at 2008, there were 25 zones registered with Nigerian Export Processing Zone Authority (NEPZA), out of which 11 zones are operational, 9 zones under construction and 5 zones merely declared. Nonetheless, thirteen (13) years after their official commissioning, there is little or no evidence that the zones have made significant impact in improving the manufacturing sector to accelerate industrialization. As earlier noted, value addition is critical in the production processes at the zones. According to Aggarwal (2010), the higher the value addition the greater EPZs' contributions to socio-economic development in the host countries. In countries where EPZs have contributed substantially to their development, value addition (production segmentation) is encouraged and enforced. This is not obvious in the Nigerian zones and has negated the industrialization expectation in the country through the zones. Yet, previous works on EPZ such as the works of Okon (2013) and Osanakpo (2013) fail to examine the nature of value addition and production segmentation in the Nigerian zones and their implications for industrialization in the country. This paper, therefore seeks to fill the gap noted in other works on EPZs in Nigeria. Hence, the objective of this paper is to determine the level and nature of value addition in the production processes at the zones in Nigeria. The rest of the paper would be developed under the following headings: the concept of EPZ, EPZs and value addition, methodology, discussion of findings and conclusion.

\section{The Concept of Export Processing Zones}

There have been divergent views with regard to what constitutes an export processing zone and what does not. Some scholars are of the view that all the zone strategies of development are one and the same, and therefore, could be classified as export processing zones, especially since their primary objective is "value addition" to products for export. To the United Nations Industrial Development Organization (UNIDO) an EPZ is "a relatively small, geographically separated area within a country, the purpose of which is to attract export-oriented industries, by offering them especially favourable investment and trade conditions as compared with the remainder of the host country". The different terms used to denote the zones scheme are Export Processing Zones (EPZs), Special Economic Zones (SEZs), Enterprise Zones (EZs), Free Port (FP), Bounded Zones (BZs), Industrial Development Zones (IDZs), etc. Obviously, EPZs take a variety of names in different countries. Singa (2007:24), identifies 32 different names/titles used for such zones around the world, each indicating slight differences in terms of concessions, subsidies and regulations. On their part, Tyler and Negrete (2009:1) observe that, while the names of the EPZs vary widely they have a number of common features, including: (a) exemption from import-related taxes; (b) exemption from indirect taxation on exports; (c) simplification in and reduction of domestic economic regulations and procedures applicable to the EPZs; (d) Freedom for foreign exchange and capital transactions; and (e) promised stability in the economic policy "rules of the game". Nonetheless, they were quick to add that even in these common features there can be substantial variants in different countries.

\section{EPZs and Value Addition: An Overview}

The major objective of the EPZ strategy is value addition to products for export. In this regard, it is argued that, "the larger the value addition, the greater is the multiplier effect" (Aggarwal, 2010:25). For exports to bring the desired benefits to the host country's economy the value addition on the products must be significant. Value addition is the totality of inputs added to the finished products from the host economies. Jenkins, et al (1998) observes that Korea's Massan EPZ in the 1970s 
witnessed its value added share of exports rise from 28 percent in 1971 to 52 percent in 1979 . This by every standard is a significant achievement in nine years period. Sanchez-Ancochea (2006) in a comparative analysis of EPZs in Costa Rica and the Dominican Republic in terms of export value added share of the total value of exports in the EPZ sectors finds significant differences. For instance, in the Dominican Republic the level of value addition was relatively higher, but the increase over time was less, from 33 percent in 1986 to 39 percent in 2002. On the other hand, Costa Rica experienced an increase from 17 percent in 1988 to 26 percent in 2002, with much volatility over the period. Out of the three countries examined it is obvious that South Korea has had most favourable value addition to its exports in its EPZs.

Aggarwal (2010:22) notes that between 2000 and 2006 the total value addition rate in EPZs in India was 48 percent. Similarly, Amirahmadi and Wu (1995) found that value addition by EPZs in Indonesia was 62 percent and 49 percent in Taiwan. Apparently, the rate of value addition in these countries' zones is impressive and favourable, and therefore was successful in creating backward economic linkages. Table 1 below shows value addition in some selected sectors in India's EPZs between 2000 and 2005.

Table 1: Sector Wise Value Addition in India 2000 - 2005

\begin{tabular}{|l|c|c|c|}
\hline Sector & Export (US \$ Million) & Import (US \$ Million) & $\begin{array}{c}\text { Net export as a percentage } \\
\text { (\%) of total Export }\end{array}$ \\
\hline Chemical and Drugs & 819.3847 & 232.4144 & 71.6 \\
\hline Electronics HW & 2269.847 & 1806.509 & 20.4 \\
\hline Electronics SW & 2413.87 & 308.5893 & 87.2 \\
\hline Engineering & 964.0784 & 540.9952 & 43.9 \\
\hline Food & 230.0963 & 27,62107 & 88.0 \\
\hline Gems and Jewelry & 8315,363 & 5137.62 & 38.2 \\
\hline Leather & 201.8 & 48.89 & 75.8 \\
\hline Rubber / Plastics & 416.91 & 142.88 & 65.7 \\
\hline Textiles & 1314.87 & 518.39 & 60.6 \\
\hline Misc & 529.2 & 190.25 & 64.0 \\
\hline Total & 17274.6 & 8969.14 & 48.1 \\
\hline
\end{tabular}

Source: Aggarwal, A. (2010), Economic Impacts of SEZs: Theoretical Approaches and Analysis of Newly Notified SEZs in India, Munich Personal RePEc Archive (MPRA) paper No. 20902.

As shown in table 1 above, there are differences in the rate of value addition in the various sectors. Nonetheless, in seven out of ten sectors value addition was above 50 percent and below 50 percent in three sectors such as electronics hardware, engineering and gems and jewelry. The author attributes the low value addition in electronics hardware to the fact that production in this sector is networked through international supply chains and that the local supply chains were not yet well developed in the country. Indeed, value addition is very critical to the success of EPZs anywhere in the world.

Stein notes that, at present, apart from a Cement factory, precast panel factory, pipe coating and machine shop, of which the products are used in the oil and gas sector domestically, assembly/manufacturing activities are lacking in the Onne Zone, though there is possibility to enhance these activities. He asserts that, the inputs in the Cement factory, precast panel factory, and pipe coating factory at the Onne Zone were imports for processing at the zone for the local market particularly oil companies. The other zones are not doing anything different with regard to value addition and backward linkages. This implies foreign domination of the zones, with little or no benefit to the local economy. Value addition and production segmentation are essential components or ingredients in production/export diversification, industrialization, technology transfer and employment generation. 


\section{Methodology}

The study adopted the descriptive survey method, therefore, it was both qualitative and quantitative in nature. The population of the study was made up of 261 Free Zone Enterprises operating in the four zones (Calabar Free Trade Zone, Oil and Gas Free Trade Zone, Onne, Snake Island Integrated Free Trade Zone, Lagos and Alscon Export Processing Zone, Ikot Abasi), selected from the 11 operational zones in the country. Twenty (20) percent proportional probability sample of the 261 FZEs was used as a sample for the study. Consequently, a total of 54 FZEs were randomly selected from the four (4) zones. In addition, 5 members of staff were purposively selected from the 54 FZEs and the 4 zonal management boards. This gave a sample size of 290 participants, which was the actual sample for the study.

There were both primary and secondary data in the work. The primary data were drawn from the 290 copies of questionnaire administered on the respondents, out of which 242 copies were properly filled and returned, while the secondary data were derived from text-books, books, journal, official documents, etc. Descriptive statistics such as frequency, average distribution and percentage were used for data analysis in the study.

\section{Result and Discussion}

The research question for which the result and discussion centered on is: What is the nature and extent/level of value addition in the production processes at the zones in Nigeria?

\subsection{Data Presentation and Analysis}

First and foremost, the participants were asked to specify specific products their firms produce at the zones. Quite a number of the products were presented by the respondents as seen in the table below. Table 2 below shows a list of some products manufactured and assembled at the zones in the country.

Table 2: Products Manufactured /Assembled at the Zones

\begin{tabular}{|l|c|}
\hline Product & Zones \\
\hline Threading and Coating of Pipe & OGTFZ \\
\hline High Pressure fluid control equipment & OGTFZ \\
\hline Dry cooler, heat pump & OGTFZ \\
\hline Air or water condensed water chiller & OGTFZ \\
\hline Remote condenser & OGTFZ \\
\hline Assembling of Air conditioners and refrigerators & CFTZ \\
\hline Garments (T-shirts) & CFTZ \\
\hline Poly Vyle Chemical (PVC) Ceiling and Windows & CFTZ \\
\hline Poly Vyle Chemical (PVC) Pipes & CFTZ \\
\hline Sport Wears & CFTZ \\
\hline Rug Carpets & CFTZ \\
\hline Auto-Disable Syringes and Safety Boxes & CFTZ \\
\hline Assembling of Generator sets, Concrete Mixers (industrial), Transformers and Heavy duty machines. & CFTZ \\
\hline Construction of oil and Gas platforms & SIIFTZ \\
\hline Jackets Bony & SIIFTZ \\
\hline Repair and Fabrication of Vessels & SIIFTZ \\
\hline Aluminum Ingots & AEPZ \\
\hline
\end{tabular}

Source: Field Survey, 2015

From table 2 it is obvious that there are a number of manufactured and assembled goods in the four zones. The nature of the products manufactured and assembled in the different zones largely reflect the industries operating in the region where the zones are located, except perhaps that of 
AEPZ - Aluminum Ingots, which is essentially a semi-finished good meant for export. For instance, threading and coating of pipe and high pressure fluid control equipment produced in the OGFTZ, Onne, are basically meant for the oil and gas industries in the south-south geo-political zone or region. Similarly, the construction of jacket bony and repair and fabrication of vessels in the SIIFTZ, Lagos, target the maritime industries in the south-west region, particularly Lagos. Contrariwise, the goods produced at the CFTZ, Calabar, are largely household/domestic goods targeted at the local market.

As earlier noted, value addition is very central to the attainment of success in the export processing zones' scheme anywhere. For the zone strategy to achieve industrialization, employment generation, wealth creation and ultimately socio-economic development value addition must take a centre stage in the EPZ operations. In this section the researcher sought to know from the respondents whether or not the manufacturing/assembling firms in the zones have value addition policy in the production processes. The responses of the 143 participants whose firms are into manufacturing/assembling and 16 participants from the regulatory agencies $(143+16=159)$ are presented in the table below.

Table 3: Availability of Value Addition Policy in the Zones

\begin{tabular}{|c|c|c|}
\hline Variables & Frequency & Percentage \\
\hline Yes & 141 & 88.7 \\
\hline No & 18 & 11.3 \\
\hline Total & 159 & 100 \\
\hline
\end{tabular}

Source: Field Survey, 2015

The above table reveals that 88.7 percent, submitted that there is value addition policy in the production process in the zones. With an overwhelming majority of 88.7 percent asserting the availability of value addition policy in the production processes in the zones suggests that this is a well enshrined policy in the export processing zone scheme in the country. With respect to the minimum value addition required at the zones the respondents held a variety of views as shown in table 4.

Table 4: Minimum Value Addition Requirement at the Zones

\begin{tabular}{|c|c|c|}
\hline Variables & Frequency & Percentage \\
\hline $1-25 \%$ & 54 & 34 \\
\hline $26-50 \%$ & 36 & 22.6 \\
\hline $51-75 \%$ & 51 & 32.1 \\
\hline $76-100 \%$ & 18 & 11.3 \\
\hline Total & 159 & 100 \\
\hline
\end{tabular}

Source: Field Survey, 2015

From the table a majority of 34 percent of the respondents asserted that the minimum value addition requirement at the zones is $1-25$ percent, while 32.1 percent of the respondents put it at 51 - 75 percent. Also, 22.6 percent of the participants disclosed that the minimum value addition requirement at the zones is $26-50$ percent, whereas 11.3 percent of them put the figure at $76-100$ percent. Implicit in these assertions is that, there are different value addition requirements for different zones and industries in the nation. On the other hand, the level of variation in the participants' views concerning the minimum value addition policy at the zones suggests that some of them may not be familiar with the actual value addition requirements of their zones.

Responding to the question on the firms' involvement in "production segmentation" at the zones, 42 percent of those whose firms are into manufacturing/assembling answered to the affirmative, while 58 percent answered to the negative. The importance of this disclosure is that 
majority of the firms, which are into manufacturing/assembling at the zones, are not involved in production segmentation. Production segmentation involves the production of the main components of a particular product in different countries, including the country in which the finished product or final production is to be made. This is an integral element of value addition in the production processes and the EPZ scheme. Table 5 shows a list of some components of firms' products sourced locally as provided by those who asserted that their firms are involved in production segmentation at the zones.

Table 5: Components of Firms' Products Sourced Locally

\begin{tabular}{|l|l|}
\hline Sewing, dying and monogramming & Labour Element \\
\hline Safety boxes and syringe barrels & Material /Labour Element \\
\hline Generating set acoustic enclosure & Labour Element \\
\hline Assemblage of Air-conditioners, refrigerator and Transformer & Labour Element \\
\hline Assemblage of air/water condensed water chiller & Labour Element \\
\hline Fabrication and repairs of ship & Technology/Labour Element \\
\hline Iron ore & Material /Labour Element \\
\hline
\end{tabular}

Source: Field Survey, 2015

From the table above, it is clear that the major component of the firms products sourced locally is the labour element. Out of the seven components sourced locally as proffered by some of the respondents four are strictly labour elements, two are material and labour elements and one is technology and labour element. It is important to state here that value addition entails three elements: Labour, technology and material elements. The technology and the material elements are the most crucial for the industrialization process of a country. Indeed, in all the seven components sourced locally in the Nigerian zones the labour element is more conspicuous and predominant in the value addition matrix.

\subsection{Discussion of Findings}

The first point has to do with the level of value addition. As noted earlier, value addition is very central to the attainment of the industrialization aspiration of Nigeria, especially through the zone strategy. In table 3, 88.7 percent of the participants attested to the fact that there exists value addition policy in the zones. It is important to note that value addition entails the labour, technology and material elements; all these elements are critical in the industrialization process. The technology and material elements are more crucial in enhancing a nation's industrialization. In Nigeria, the labour element is most observable than the other two elements. In other words, most of the goods produced at the zones are near-finished products, for there are no technological and material addition/input from the local economy, except the labour of Nigerians working in such firms put in the production processes. In most countries where EPZs have contributed to the industrialization and diversification of the economy value addition is reasonably high. For instance, Jenkins, et al (1998) observes that, as at 1979, the Massan EPZ in Korea had achieved 52 percent value addition in the production processes. This, to a significant degree positively influenced the industrialization expectations of the country. Similarly, Aggarwal (2010) puts the level of value addition in the EPZs in India and Indonesia in 2006 at 48 percent and 62 percent respectively. The high level of value addition at the zones in these countries enhanced the backward integration with the domestic economies. Backward integration/linkage involves internal steps taken to reduce overall dependency on things like suppliers and service providers. In other words, it makes major components of products (materials and technology) to be sourced from the local market. Most often, backward integration reduces production cost (for example through cut in transportation cost), improve profit margin and make the firms more competitive in the global market.

Also, majority of those whose firms are into manufacturing/assembling at the zones disclosed that their firms have achieved over 40 percent value addition. However, as seen in table 5 the bulk 
of what was sourced locally in the production process at the zones is labour. Put differently, the labour element of value addition is the dominant input in the Nigerian zones. Obviously, as noted earlier, for exports of manufactured goods to bring the desired benefits to the host country's economy the value addition (components of the product sourced locally) on the products must be significant, particularly in the area of technology and material input. As Aggarwal (2010) puts it, "the larger the value addition, the greater is the multiplier effect".

The second factor is the near absence of production segmentation arrangement at the zones in the country. Production segmentation involves an arrangement in which certain main components of a manufactured product are produced by different firms in the same country or different countries. This encourages specialization of the different firms in the area or aspect of the product assigned to them for production. For instance, Milberg and Amengual (2008), observe that, in 1994 firms in the zones in Malaysia and the Philippines have a combined share of 10 percent of the world export of transistors and valves in electronics production. In the case of Nigeria, even though 42 percent of the participants whose firms are involved in manufacturing/assembling claimed that their firms are involved in production segmentation arrangement, apart from those in Rusal-Alscon, none could disclose what main component of a product their firms produce, the industries and the destination of the component/product. Even the product of Rusal-Alscon, "aluminum ingots", is essentially a processed raw material and cannot be classified as a main component of a manufactured product in the strict sense of the production segmentation thinking. Production segmentation is a critical element of value addition and it is key to economic diversification and industrialization.

Lastly, the share of value addition in EPZ manufactured exports help in economic diversification and ultimately industrialization. For EPZs to contribute meaningfully towards economic diversification in Nigeria, value, addition levels in EPZs exports must be reasonably high. Clearly in Nigeria, EPZs have not helped in the diversification of the economy. Nigeria is still a monocultural, oil based, economy, getting about 90 percent of her export earnings from oil exports. Globally, a number of countries have diversified their economies through increasing the share of value addition in EPZs manufactured exports. For instance, ILO (2003) opined that Mauritius used the zone scheme to shift from exporter of primary commodities such as sugar to an exporter of manufactured goods. Similarly, India has used the zone scheme to diversify its economy from labour-intensive agricultural economy to capital-intensive and technology driven industrial economy (Aggarwal, 2010).

\section{Conclusion}

What has become very clear from the discussion above is that the Nigerian government adopted the EPZ strategy in 1992 on the recommendation of the UNIDO, to accelerate industrialization process through increased value addition. While there is value addition policy in the EPZ scheme, it has not being properly encouraged and enforced to produce the desired outcome. Hence, value addition, particularly the technology and material elements, is next to zero at the zones in the country. Only the Labour element of value addition is visible at the zones in the country. Consequently, the zone strategy in Nigeria has not contributed substantially to meet the industrialization expectation of the nation. In countries where the zone strategy has helped industrialization, such as India, China, Indonesia, Korea, etc, the level of value addition is reasonably high in the production processes at the zones, especially technology and material elements of value addition. Therefore, the conclusion of this paper is that the EPZ strategy has failed to achieve export of manufactured goods and industrial in Nigeria because of the low level value addition and absence of production segmentation arrangements. For the EPZ strategy to help meaningfully in the industrialization drive of Nigeria, value addition and production segmentation must be made mandatory in the manufacturing and assembling processes at the zones. This was what the Asian countries did to achieve relative growth in the industrial sectors through the zones. 


\section{Recommendations}

Sequel to the above findings the following recommendations are made:

(i) Value addition should be made compulsory in the production processes at the zones. This will encourage backward linkages with the domestic economy and accelerate the process of industrialization of the country through the zones.

(ii) Technology and material elements of value addition should be emphasized in the production processes at the zones. Deliberate policy should be put in place in this regard at the zones.

\section{References}

Aggarwal, A. (2010), Economic Impacts of SEZs: Theoretical Approaches and Analysis of Newly Notified SEZs in India, Munich Personal RePEc Archive (MPRA) paper No. 20902. Pp. 22-24

Amirahmadi, H. and Wu, W. (1995), "Export Processing Zones in Asia," in Asian Survey, Vol. 35, (September 1995), Pp $828-849$.

Harry, D.M. (2016), Export Processing Zones and Economic Diversification in Nigeria, 2001 - 2013, International Journal of Political and Administrative Studies, Vol. 2, No. 2. Pp. 24-27.

ILO (2003) Employment and Social Policy in Respect of Export Processing Zone (EPZs), Governing Body, Committee on Employment and Social Policy, Geneva: International Labour Office, (March 2003). Pp. 12 $-14$.

Jenkins, M., Gerardo, E. and Felipe, L.B. (1998), Export Processing Zones in Central America, Development Discussion Paper No 646, Harvard Institute for International Development, Harvard University.

Milberg, W. and Amengual, M. (2008), Economic Development and Working Conditions in Export Processing Zones: A Survey of Trends, Working paper No. 3, Geneva: International Labour Office. Pp. 11-12.

NEPZA (2008), Nigerian Export Processing Zones Authority Brochure, www.nepza.gov.ng/

Okon, E.E. (2013), Free Trade Zone: Policies, Principles and Problems, in Azinge, E. and Omo S. (ed), Legal Regime of Free Trade Zones, Lagos: NIALS Press. Pp. 13-17.

Osanakpo, O. (2013), Free Trade Zones and Industrialization, in Azinge, E. and Omo S. (ed), Legal Regime of Free Trade Zones, Lagos: NIALS Press. Pp. $209-227$.

Sanchez-Ancochea, D. (2006), Development Trajectories and New Comparative Advantages: Costa Rica and the Dominican Republic Under Globalization, World Development, Vol. 34. Issue 6. Pp 996 -1015.

Singa, B.J. (2007), ILO Database on Export Processing Zones (Revised), Sectoral Activities Programme, Working Paper 251, Geneva: International Labour Organization. April, 2007, Pp.1 \& 22.

Stein, H. (2008), "Africa, Industrial Policy and Export Processing Zones: Lessons from Asia", A paper prepared for Africa Task Force Meeting, Addis Ababa, Ethiopia, July 10 - 11. Pp. 1- 4

Tyler, W.G. and Negrete A.C.A. (2009), Economic Growth and Export Processing Zones: An Empirical Analysis of Policies to cope with Dutch Disease, A paper prepared for the LASA 2009 Congress, Rio de Janeiro, June 11 - 14. Pp. $1-13$.

UNIDO (1980), Export Processing Zones in Developing Countries, New York: United Nations Industrial Development Organization. 